\title{
A Simple Device to Evaluate the Influence Parameters of the Water Erosion of Bare Sandy-Clay Soils of the City of Douala
}

\author{
Timothée Thierry Odi Enyegue1, Didier Fokwa',2, Eric Flavien Mbiakouo-Djomo3, \\ Ebenezer Njeugna ${ }^{1,3}$
}

${ }^{1}$ Doctoral Unit of Engineering Sciences, Laboratory of Mechanical Engineering, ENSET, University of Douala, Douala, Cameroon ${ }^{2}$ Department of Civil Engineering ENSET, Douala University, Douala, Cameroon

${ }^{3}$ Department of Mechanical Engineering, Douala University, Douala, Cameroon

Email: oditimothee@yahoo.fr

How to cite this paper: Enyegue, T.T.O., Fokwa, D., Mbiakouo-Djomo, E.F. and Njeugna, E. (2019) A Simple Device to Evaluate the Influence Parameters of the Water Erosion of Bare Sandy-Clay Soils of the City of Douala. Engineering, 11, 819-827. https://doi.org/10.4236/eng.2019.1112056

Received: November 14, 2019

Accepted: December 21, 2019

Published: December 24, 2019

Copyright (c) 2019 by author(s) and Scientific Research Publishing Inc. This work is licensed under the Creative Commons Attribution International License (CC BY 4.0).

http://creativecommons.org/licenses/by/4.0/

\begin{abstract}
We explore the parameters that influence the dynamics of water erosion. The method used is an experimental laboratory simulation, which consists of the quantitative evaluation of eroded masses as a function of slope, soil cohesion and rainfall intensity. A simulator was designed to have the ability to vary the slope of the terrain, as well as the rainfall intensity. The variation of the soil cohesion is obtained by compacting the soil under different pressures using a hydraulic press associated with the whole experimental device. The results obtained show that the device is a good tool to simulate in the laboratory the behavior of different soil under the action of rain; because these results are in agreement with existing models USLE, MUSLE and RUSLE [1] [2] [3] [4].
\end{abstract}

\section{Keywords}

Water Erosion, Mini-Rain Simulator, Cohesion of a Soil, Simulation, Slope

\section{Introduction}

The soil is made up of particles ranging in size from a few microns to a few centimetres depending on the nature of the parent rock or geological history. In this complex, fine particles make up the binder, while the larger ones make up the skeleton. As rainwater passes, some particles are torn off and then washed away under the double effect of falling drops and the speed of flow, when the soil has a critical slope: it is water erosion. Erosion has the effect of lowering the soil level in relief areas and increasing it in the shallows where sedimentation is due to the 
inability of the current to transport the particles. The aim of this work is to do an experimental study of the dynamics of erosion. To this end we will analyze first the influence of the slope, then the effect of compaction on erosion and sediment transport, and finally an analysis of the influence of rainfall intensity.

\section{Materials}

Figure 1 shows the diagram of the entire OEF (Odi Enygue Fokwa) rain simulator. This mini rain simulator includes a tank (1), a pump (2), a soil sample support (3), a sprinkler system with valves and watering cans (5), a pressure tank (6), an infiltrating water recovery tank (7), a reservoir retrieving dripping water (8), a pressure tank support (9), a pressure tank supply channel (10), a rain generation system supply channel (11), a channel for the release of excess water from the tank. In addition to this system, a compacting press and moulds are combined, allowing to obtain at a given pressure blocks of soil that will have to be placed in the tray. See Figure 2 .

\section{Method}

The method used is an experimental simulation in the laboratory, allowing to multiply the scenarios of rain in the laboratory from variations in watering rates, to model different types of topographies in particular by modelling them from degrees of soil compaction for variations in soil particle cohesion, and modelling of different slopes. These parameters can then be used for natural basin identification and linear interpolation to help predict natural erosion. The device works as follows: The tank (1) is the source of the water used, the pump (2) allows to take the water from (1) and push it back into the pressure tank (6), the soil sample holder (3) whose slope is adjustable allows to model different slopes, the soil sample (4) used is a sablo-clay mixture consisting of a percentage of clay varying between 25 and 30, watering cans (5) can simulate the fall of the rains. The tank (6) is poised at 1.5 meters above tank (1), allows to regulate the pressure of the water at the watering system; this tank is connected to a duct (12) of returns excess water to (1) in order to keep the pressure at the desired value. The tank (7) allows the recovery of infiltrated water, the tank (8) is used for the recovery of dripping water, the support of the pressure tank (9) keeps it in balance and altitude, the hose (10) allows the supply of the pressure. A stem (11) allows the power of the rain generation system. The simulator itself is a set of pipes and faucets as shown in Figure 1 and allows the intensity of rainfall to vary.

This rain simulator works according to the fluid dynamics conservation equation, i.e.:

The sum of incoming flows is equal to the sum of outgoing flows such as:

$$
Q_{p}=Q_{a}+Q_{r}
$$

$Q_{p}$ is the flow of water repressed by the motor pump;

$Q_{a}$ is the watering rate;

$Q_{r}$ is the flow of water. 


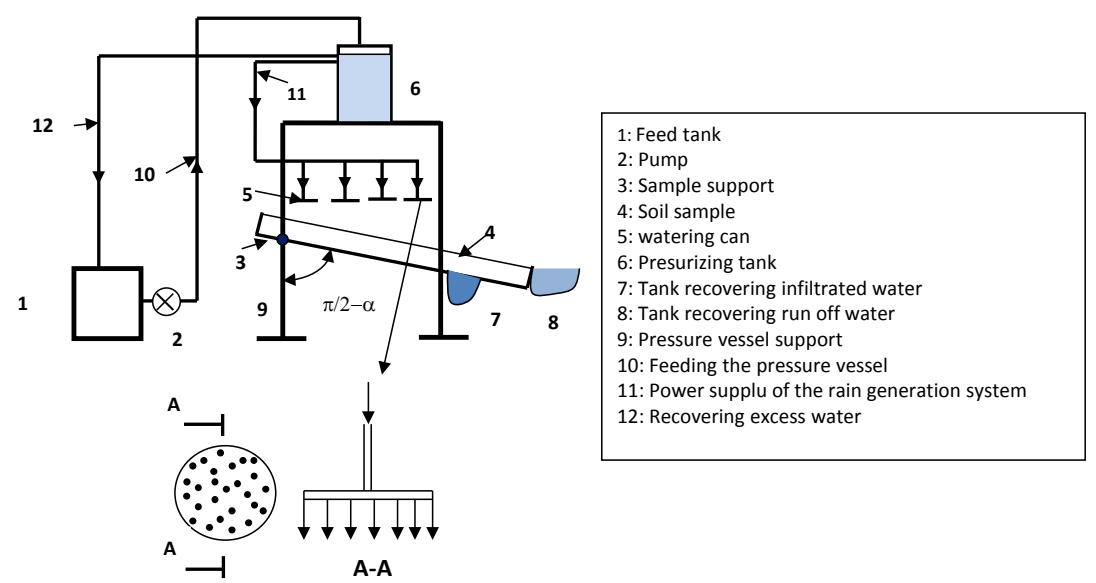

Figure 1. Overview of the experimental setup.

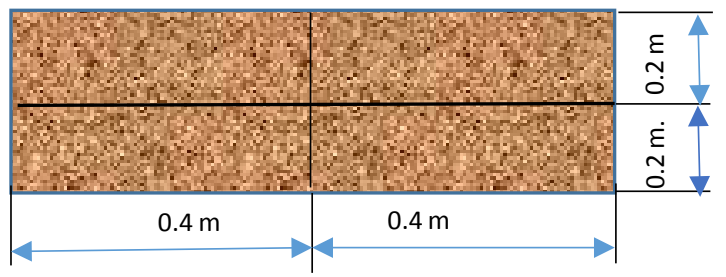

Figure 2. Soil sample compacted at a given pressure.

$$
Q=S \cdot v=V / t \quad Q\left(\mathrm{~m}^{3} / \mathrm{s}\right), S\left(\mathrm{~m}^{2}\right), \quad v(\mathrm{~m} / \mathrm{s}), \quad V\left(\mathrm{~m}^{3}\right) \text { and } t(\mathrm{~s})
$$

The assessment of the masses of eroded soils is done by the mass conservation formula:

$$
m_{\text {eroded soil }}=m_{\text {total }}-\rho_{\text {water }} V_{\text {water sprinkled }}
$$

$m_{\text {total }}$ is the mass of the soil + water mixture: it is the mass obtained by weighing all the water collected from the different reservoirs of the infiltrated and run-off water.

$V_{\text {water sprinkled }}$ is the volume of water used to irrigate the soil sample.

\section{Data for the Experiment}

Soil sample (C): The soil sample is compacted at different pressures $\left(0.5 \mathrm{~N} / \mathrm{mm}^{2}\right.$ $-0.7 \mathrm{~N} / \mathrm{mm}^{2}-0.9 \mathrm{~N} / \mathrm{mm}^{2}-1 \mathrm{~N} / \mathrm{mm}^{2}$ ). For each test series, 4 blocks of the soil sample, compressed under the same intensity, are placed in the tray, corresponding to the surface of the tray. Between the contact surfaces of the blocks the ground has a scratched appearance. To ensure the continuity of the ground, a tiny amount of moistened soil is inserted, then the whole is compacted and dried. Discontinuity is one of which by this neglected procedure. We can only consider the presence of micro-accidents frequent of a real field [5].

Observation time $(\mathrm{t})$ : it is set at $2 \mathrm{~min}(120 \mathrm{~s})$ per test.

Simulated rainfall: The tests are carried out in simulated rain, resulting in runoff with variation in rain intensity through the opening of the valves. The watering flows used in the experiment are: $Q 1=0.125 \mathrm{~L} / \mathrm{s}, Q 2=0.25 \mathrm{~L} / \mathrm{s} Q 3=$ 
$0.375 \mathrm{~L} / \mathrm{s}$ and $Q 4=0.5 \mathrm{~L} / \mathrm{s}$. Here, the $P$ pressure is maintained consistently for each test and is defined by the formula:

Pout $=$ Patm + o.g.h; then: $P=10+104 \times 0.7=7010, \mathrm{~Pa}=7.01 \times 10^{-3} \mathrm{MPa}$.

The slope $(\alpha)$ : The slopes variations are going: $0^{\circ}-5^{\circ}-8.2^{\circ}-15.9^{\circ}-20^{\circ}$.

\section{Results and Discussion}

\subsection{Presentation of the Results}

The results of the weights weighed according to compaction and slopes are grouped in Table 1 below.

Table 1. Grouping of masses (g) according to compaction, angles and water flow.

\begin{tabular}{|c|c|c|c|c|c|c|}
\hline \multicolumn{2}{|c|}{ Valeurs d'angles } & $0^{\circ}$ & $5^{\circ}$ & $8.2^{\circ}$ & $15.9^{\circ}$ & $20^{\circ}$ \\
\hline \multirow{5}{*}{$\mathrm{C} 1=0.5 \mathrm{~N} / \mathrm{m}^{2}$} & Masse à $Q 1=0.125 \mathrm{~L} / \mathrm{s}$ & 80.67 & 453.86 & 478.07 & 631.42 & 816.53 \\
\hline & Masse à $Q 2=0.25 \mathrm{~L} / \mathrm{s}$ & 164.30 & 480.68 & 490.56 & 673.79 & 875.98 \\
\hline & & & & & & \\
\hline & Masse à $Q 3=0.375 \mathrm{~L} / \mathrm{s}$ & 281.35 & 532.59 & 585.15 & 689.45 & 895.43 \\
\hline & Masse à $Q 4=0.5 \mathrm{~L} / \mathrm{s}$ & 297.96 & 558.63 & 611.29 & 715.86 & 938.87 \\
\hline \multirow{4}{*}{$\mathrm{C} 2=0.7 \mathrm{~N} / \mathrm{m}^{2}$} & Masse à $Q 1=0.125 \mathrm{~L} / \mathrm{s}$ & 58.22 & 404.29 & 430.94 & 489.87 & 581.18 \\
\hline & Masse à $Q 2=0.25 \mathrm{~L} / \mathrm{s}$ & 135.97 & 457.83 & 482.00 & 576.51 & 670.05 \\
\hline & Masse à $Q 3=0.375 \mathrm{~L} / \mathrm{s}$ & 211.25 & 482.68 & 506.13 & 612.42 & 716.67 \\
\hline & Masse à $Q 4=0.5 \mathrm{~L} / \mathrm{s}$ & 232.42 & 503.67 & 528.98 & 690.68 & 797.86 \\
\hline \multirow{4}{*}{$\mathrm{C} 3=0.9 \mathrm{~N} / \mathrm{m}^{2}$} & Masse à $Q 1=0.125 \mathrm{~L} / \mathrm{s}$ & 57.86 & 320.68 & 335.47 & 405.18 & 414.86 \\
\hline & Masse à $Q 2=0.25 \mathrm{~L} / \mathrm{s}$ & 85.84 & 335.04 & 392.95 & 501.94 & 538.34 \\
\hline & Masse à $Q 3=0.375 \mathrm{~L} / \mathrm{s}$ & 135.98 & 392.42 & 435.07 & 556.53 & 607.67 \\
\hline & Masse à $Q 4=0.5 \mathrm{~L} / \mathrm{s}$ & 163.37 & 422.69 & 478.19 & 580.67 & 678.30 \\
\hline \multirow{5}{*}{$\mathrm{C} 4=1 \mathrm{~N} / \mathrm{m}^{2}$} & Masse à $Q 1=0.125 \mathrm{~L} / \mathrm{s}$ & 27.07 & 212.09 & 213.34 & 266.24 & 398.32 \\
\hline & Masse à $Q 2=0.25 \mathrm{~L} / \mathrm{s}$ & 29.85 & 272.58 & 277.84 & 361.68 & 401.30 \\
\hline & & & & & & \\
\hline & Masse à $Q 3=0.375 \mathrm{~L} / \mathrm{s}$ & 61.23 & 303.16 & 341.95 & 397.21 & 458.92 \\
\hline & Masse à $Q 4=0.5 \mathrm{~L} / \mathrm{s}$ & 88.34 & 349.63 & 394.02 & 455.87 & 506.13 \\
\hline
\end{tabular}

\subsection{Graphic Analysis of Data}

The diagrams represented by the respective figures: Figures 3-6, show the evolution of the soil masses eroded as a function of the slopes and degrees of compaction, for a constant flow rate and a duration of $120 \mathrm{~s}$.

The diagram shown in Figure 7 below shows the evolution of eroded soil masses as a function of the flow rates.

\subsection{Discussions}

An observation of these results provides the following Table 2 of extreme values. 
Table 2. Maximum and min values of soil recorded at extreme slope values and compression.

\begin{tabular}{|c|c|c|c|c|}
\hline & $\begin{array}{c}\text { Water flow } \\
Q_{1}=0.125 \mathrm{~L} / \mathrm{s}\end{array}$ & $\begin{array}{c}\text { Water flow } \\
Q_{2}=0.25 \mathrm{~L} / \mathrm{s}\end{array}$ & $\begin{array}{c}\text { Water flow } \\
Q_{3}=0.375 \mathrm{~L} / \mathrm{s}\end{array}$ & $\begin{array}{l}\text { Water flow } \\
Q_{4}=0.5 \mathrm{~L} / \mathrm{s}\end{array}$ \\
\hline $\begin{array}{l}\text { Plus faibles } \\
\text { masses en } \mathbf{g}\end{array}$ & 27.07 & $\begin{array}{l}29.87 \\
\text { Values read fo }\end{array}$ & $\begin{array}{c}61.23 \\
=0^{\circ} \text { et } C 4=1\end{array}$ & 88.34 \\
\hline $\begin{array}{l}\text { Plus grandes } \\
\text { masses en } \mathbf{g}\end{array}$ & 816.53 & $\begin{array}{l}\mathbf{8 7 5 . 9 8} \\
\text { Values read for }\end{array}$ & $\begin{array}{c}895.43 \\
20^{\circ} \text { et } \mathrm{C} 1=0.5\end{array}$ & 938.87 \\
\hline
\end{tabular}

Diagram comparing eroded masses according to slopes and compaction pressures for a flow rate $Q=0.125 \mathrm{~L} / \mathrm{s}$

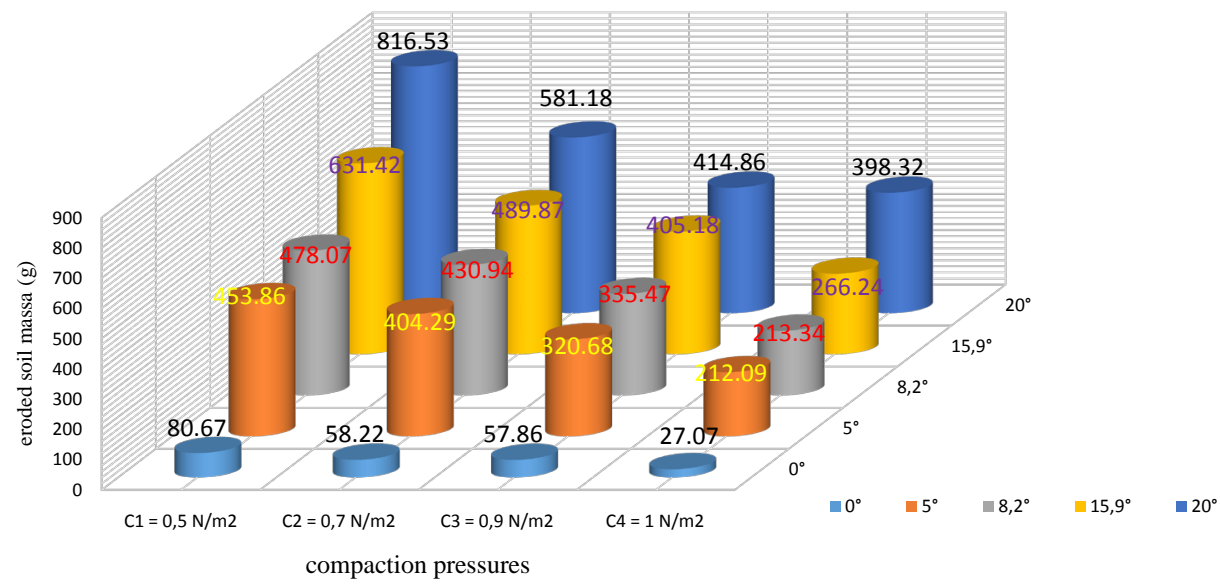

Figure 3. Mass flow chart (g) sorted at flow $Q 1=0.125 \mathrm{~L} / \mathrm{s}$.

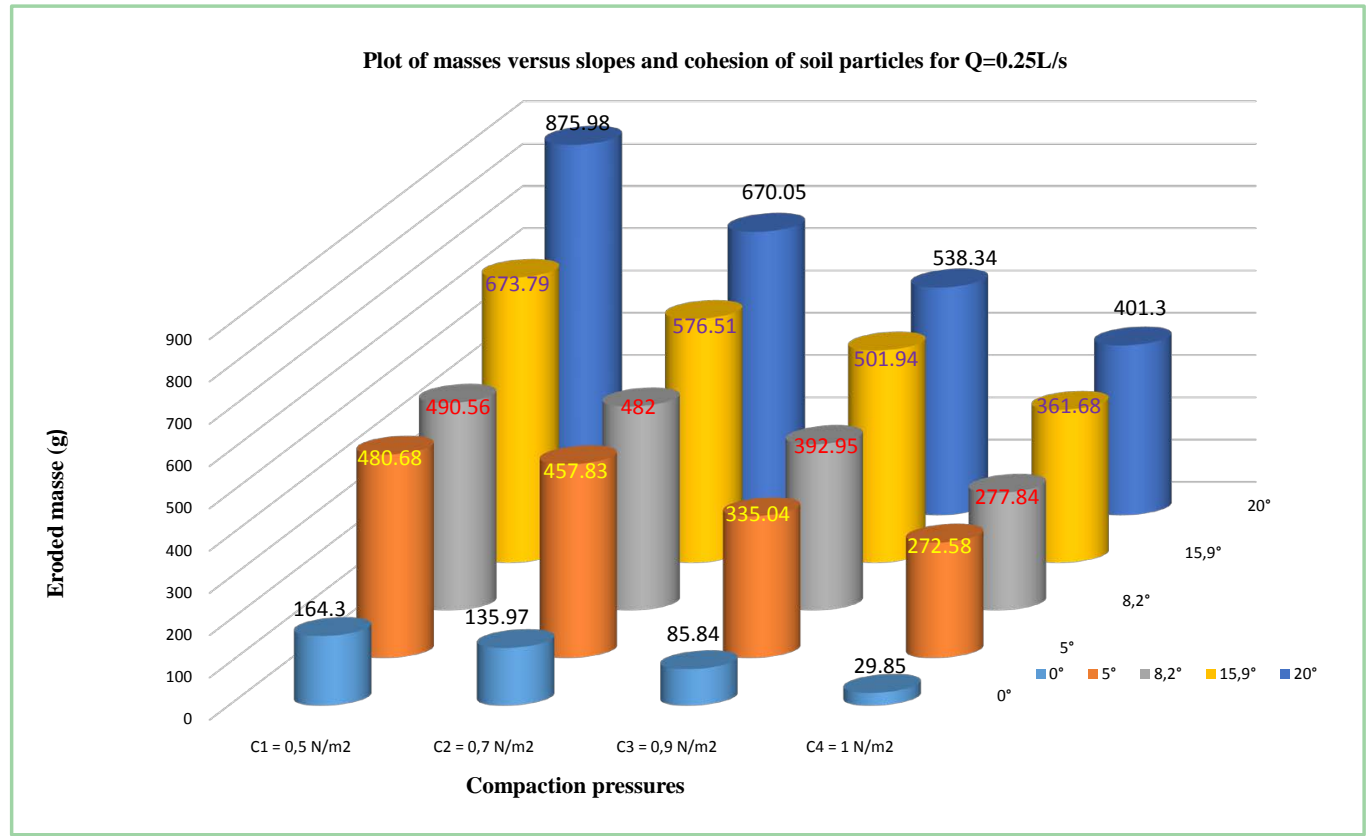

Figure 4. Mass flow chart (g) sorted at flow $Q 2=0.25 \mathrm{~L} / \mathrm{s}$. 
From the various diagrams obtained, we can make the following observations:

For a soil sample under a given constraint, for the same flow, soil losses are increasing with increasing slope values (angles);

From this observation we can conclude that erosion is greater for the large slopes; this is in keeping with the formula of the universal soil loss equation. To read [5]-[10].

1) For a given slope, with the same water flow, soil losses change downwards to larger stress samples;

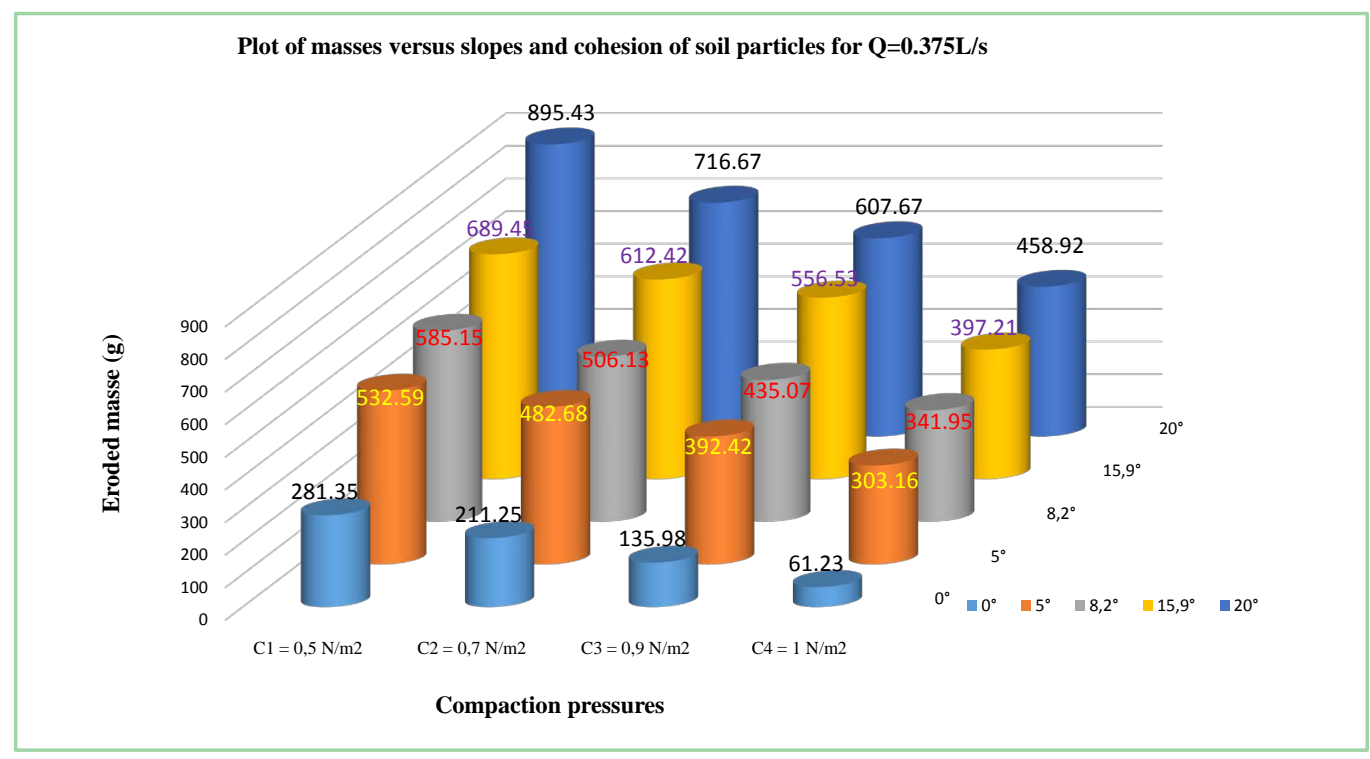

Figure 5. Mass flow chart (g) sorted at flow $Q 1=0.375 \mathrm{~L} / \mathrm{s}$.

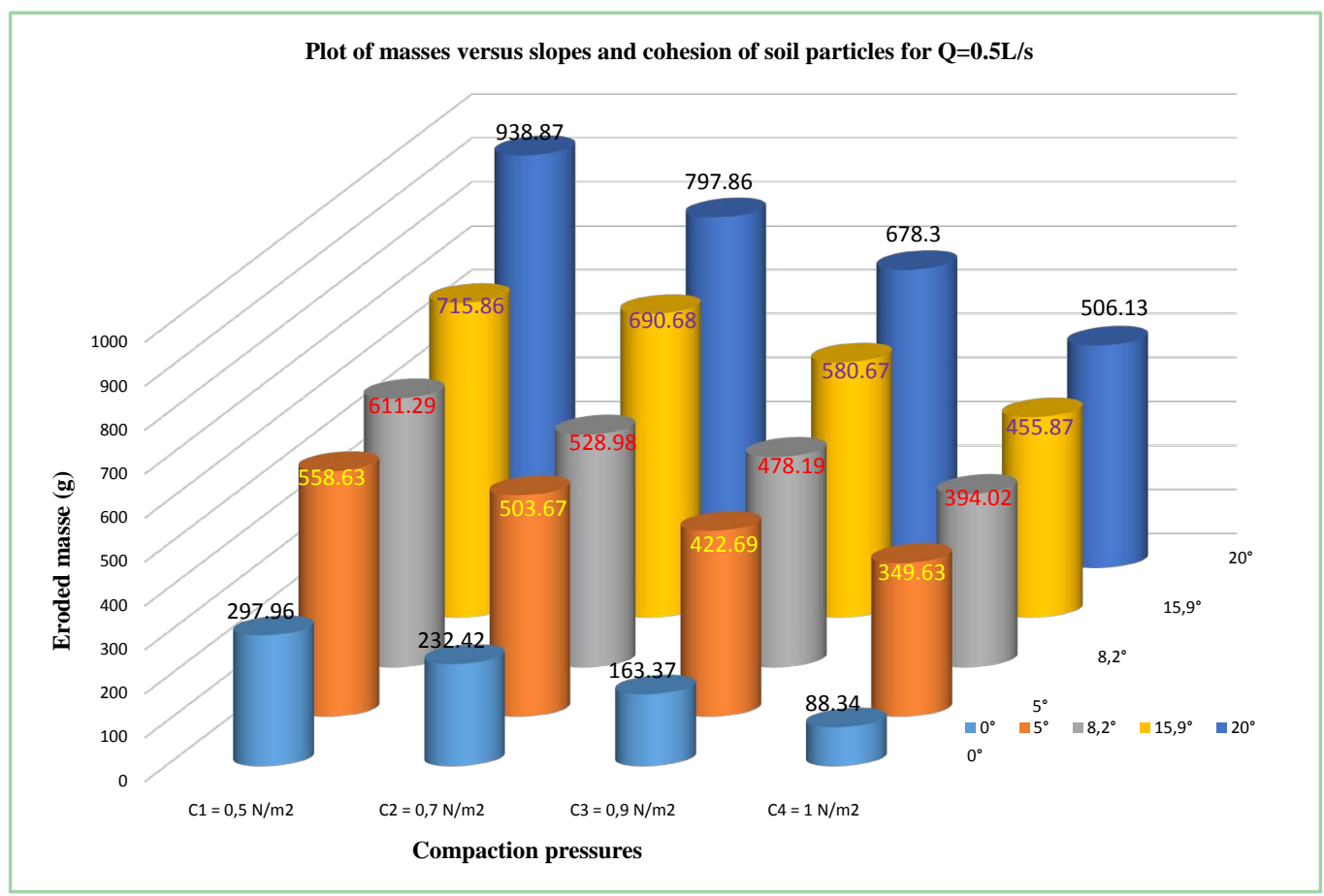

Figure 6. Mass flow chart (g) sorted at flow $Q 1=0.5 \mathrm{~L} / \mathrm{s}$. 


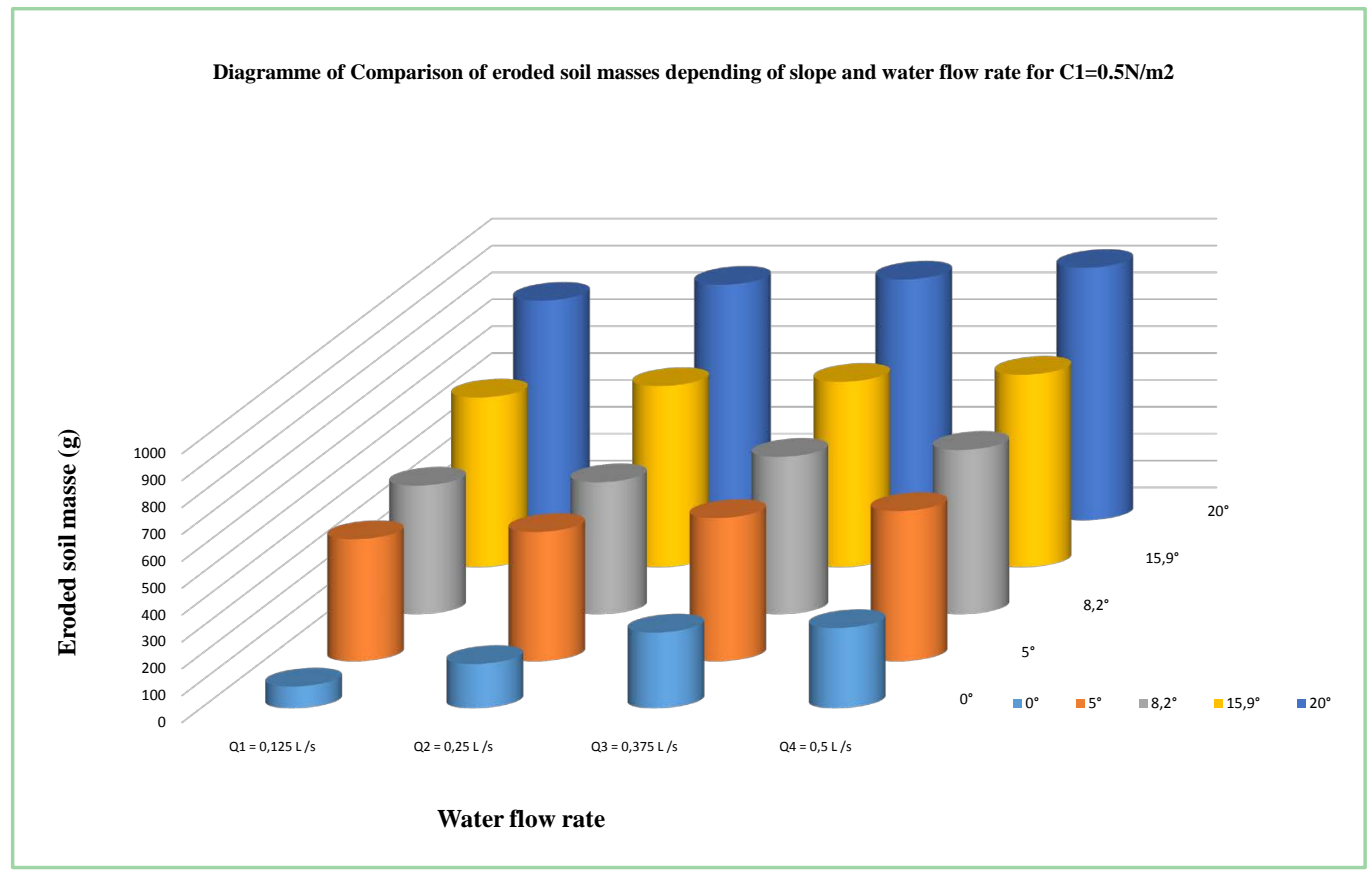

Figure 7. Mass series $(\mathrm{g})$ for a sample compacted at $\mathrm{C}=0.5 \mathrm{~N} / \mathrm{m}^{2}$.

This second observation allows us to note that erosion decreases as soil particle cohesion increases. Read [11] [12] [13] [14].

2) For a given soil and slope constraint, soil losses are increasing towards the largest rainfall flows.

From this last observation we can say that erosion increases with the high intensities of rain. This is in agreement with the authors [15] [16] [17] [18] [19].

\section{Conclusion}

The realization of a device to study the dynamics of water erosion on soils in the city of Douala, was the subject developed throughout this study and contributed favorably to the collection of data from the Douala V Area having leads to satisfactory results. From these results, it appears that for a given stress soil sample, soil losses are increasing lying for the values of the increasing slopes; whereas for a given slope, soil losses tend to shift downwards to larger stress samples. Also, for a given soil and slope constraint, soil losses are increasing towards the greater rainfall intensities. There is still a way to assess the rate of influence of soil compression on soil loss; this would be possible with a larger database. We also want to see this device improved through the addition of a quantified pressure variation accessory, with automation of some controls making the device more convenient and reliable.

\section{Conflicts of Interest}

The authors declare no conflicts of interest regarding the publication of this paper. 


\section{References}

[1] Wischmeier, W.H. and Smith, D.D. (1978) Predicting Rainfall Erosion Losses: A Guide to Conservation Planning. Science and Education Administration, US Department of Agriculture.

[2] Wischmeier, W.H. (1984) The USLE: Some Reflections. Journal of Soil and Water Conservation, 39, 105-107.

[3] Renard, K.G., Foster, G.R., Weesies, G.A. and Porter, J.P. (1991) RUSLE: Revised Universal Soil Loss Equation. Journal of Soil and Water Conservation, 46, 30-33.

[4] Renard, K.G. and Ferreira, V.A. (1993) RUSLE Model Description and Database Sensitivity. Journal of Environmental Quality, 22, 458-466. https://doi.org/10.2134/jeq1993.00472425002200030009x

[5] Bilaşco, Ş., Horvath, C., Cocean, P., Sorocovschi, V. and Oncu, M. (2009) Implementation of the USLE Model Using GIS Techniques. Case Study the Someşean Plateau. Carpathian Journal of Earth and Environmental Sciences, 4, 123-132.

[6] Song, Z., Wu, T., Xu, F. and Li, R. (2008) A Simple Formula for Predicting Settling Velocity of Sediment Particles. Water Science and Engineering, 1, 3743. https://doi.org/10.1016/S1674-2370(15)30017-X

[7] Renard, K.G., Foster, G.R., Weesies, G.A. and Porter, J.P. (1991) RUSLE: Revised Universal Soil Loss Equation. Journal of Soil and Water Conservation, 46, 30-33.

[8] Ahmad, I. and Verma, M.K. (2013) Application of USLE Model \& GIS in Estimation of Soil Erosion for Tandula Reservoir. International Journal of Emerging Technology and Advanced Engineering, 3, 570-576.

[9] Devatha, C.P., Deshpande, V. and Renukaprasad, M.S. (2015) Estimation of Soil Loss Using USLE Model for Kulhan Watershed, Chattisgarh-A Case Study. Aquatic Procedia, 4, 1429-1436. https://doi.org/10.1016/j.aqpro.2015.02.185

[10] Markhi, A., Laftouhi, N.-E., Soulaimani, A. and Fniguire, F. (2015) Quantification et evaluation de l'erosion hydrique en utilisant le modèle rusle et déposition intégrés dans un sig. application dans le bassin versant n'fis dans le haut atlas de marrakech (MAROC). European Scientific Journal, 11, 340-356.

[11] Christensen, R.W. and Das, B.M. (1973) Hydraulic Erosion of Remolded Cohesive Soils. Highway Research Board Special Report, 8-19.

[12] Ariathurai, R. and Arulanandan, K. (1978) Erosion Rates of Cohesive Soils. Journal of the Hydraulics Division, 104, 279-283.

[13] Raudkm, A.J. and Tan, S.K. (1984) Erosion of Cohesive Soils. Journal of Hydraulic Research, 22, 217-233. https://doi.org/10.1080/00221688409499380

[14] Brunier-Coulin, F. (2015) Mécanismes élémentaires de l'érosion d'un sol cohesive. Congrès français de mécanique.

[15] Ellison, W.D. (1944) Studies of Raindrop Erosion. Journal of Agricultural Engineering, 25, 131-136.

[16] Badr, S. (2014) Erosion d'un milieu granulaire par un jet.

[17] Houichi, L. (2017) Formule appropriee pour l'estimation de l'intensite de pluie de duree et de frequence voulue: Un cas d'etude (Appropriate Formula for Estimating Rainfall Intensity of Selected Duration and Frequency: A Case Study). Larhyss Journal, 30, 67-87.

[18] Abossolo, S.A., Amougou, J.A. and Tchindjang, M. (2017) Perturbations climatiques et pratiques agricoles dans les zones agroécologiques du Cameroun: Changements so-cio-économiques et problématique d'adaptation aux bouleversements climatiques. 
Editions Publibook.

[19] Mbiakouo, E.F., Njeugna, E., Tcheukam-Toko, D. and Fokwa, D. (2018) Quantification and Evaluation of Soil Erosion in the Estuaries of Cameroon, Gulf of Guinea: Case of Nylon Area. Applied and Environmental Soil Science, 2018, Article ID: 8562698. https://doi.org/10.1155/2018/8562698 